\title{
On Inflation Accounting in China
}

\author{
Zhenghong Che \& Xianxue Li \\ School of Economics and Management, Changchun University of Science and Technology \\ No. 7989, Weixing Road, Changchun 130022, Jilin, P.R. China \\ E-mail: czh912@126.com
}

Received: December 30, 2010

Accepted: February 15, 2011

doi:10.5539/mas.v5n2p156

\begin{abstract}
Recently, China has a more prominent trend of domestic price rise, which has obviously influenced public's daily life and corporate production and operation. If we don't take effective measures to deal with price trend, it will lead to further strengthened inflation expectation and deteriorate market economy order. Business community is actively seeking countermeasures to deal with the impact of inflation, and discuss how to circumvent the risks of inflation by using of inflation accounting.
\end{abstract}

Keywords: Inflation, Price rise, Accounting model

The economic data of November 2010 by China National Bureau of Statistics show that consumer price Index (CPI) in November rose by $5.1 \%$ compared to the same period of last year, reaching the highest record within 28 months, and rose by $1.1 \%$ compared to last month. Producer price index (PPI) rose by $6.1 \%$ and $1.4 \%$ respectively. With further strengthened inflation expectation, the accounting practice on dealing with the impact of price change has become an addressed issue among accounting theorists.

\section{Emergence and development of inflation accounting}

Inflation accounting is a kind of accounting procedure and method, which is under inflation condition, according to the general price index or current cost data, adjusts traditional historical cost accounting in order to reflect and offset the influence of price rise on traditional accounting statement, or completely change some traditional accounting principles, and reflects corporate financial situation and business achievement more realistically.

Inflation accounting is a new field of western financial accounting, whose emergence and development has very deep historical background. Along with the transition of capitalist economy from free competition to monopoly, cyclical economy crisis has emerged. Especially after World War I, western countries experienced inflation, price rise and large unemployment, which broke the balance and stability of economy running. Inflation, unemployment, and serious imbalance of resource allocation became a sort of reflection of deepened and complicated economy crisis of capitalist countries, which hindered the development of capitalist economy. Western economic theorists have made long-term unremitting exploration and research in order to control serious inflation; however, they have not been able to fundamentally eliminate the inflation phenomenon.

Several stages of the emergence and development of inflation accounting. 1. In the traditional financial accounting method, appropriate methods are used to eliminate the influence of inflation on traditional financial accounting information. (1) LIFO of paying the cost of inventory; (2) accelerated depreciation of fixed assets; (3) valuation of periodic replacement of fixed assets; (4) no depreciation of fixed assets. 2. Adjust traditional financial accounting information to reflect and eliminate the influence of inflation according to general price change. 3. Reflect the change of corporate assets during inflation based on current cost, and provide statement user with accounting information influenced by traditional financial accounting of individual price change.

\section{The implementation of inflation accounting is a necessary requirement for economic development in China}

At present, China's corporate accounting is mainly based on historical cost, with corresponding accounting requirements on assets, liabilities, equity, costs, expenses, income and other accounting elements. However, in the case of inflation, due to increased money supply, real purchasing power declines. If we follow traditional assumption of unchanged currency and historical cost principle of accounting, it will inevitably lead to distortion, resulting in a series of negative effects. Therefore, it is an economic necessity to actively promote inflation accounting, which is the premise to ensure the accuracy, relevance and usefulness of accounting information. 


\subsection{It is a need to promote inflation accounting for improving the stability of accounting units}

The traditional assumption of unchanged currency and historical cost accounting model consider neither changes in monetary value nor price changes of measured production factors, therefore it can't reflect the information of price changes. In the case of continuous inflation, the use of this accounting model will lead to the following serious problems. What the historical cost accounting uses is named currency unit. In the case of price change, the result must be lack of economic practical significance. When price rises, the historical cost of assets may be much lower than the market price of prepared statement, which is difficult to reflect assets, especially the real value of fixed assets. Monetary depreciation of assets will cause loss of purchasing power to some degree; the real value of assets held is undervalued, and equity is underestimated in the whole. So it seriously affects the accuracy of financial statement, greatly reduces the usefulness of accounting information, and even affects the benefits of the company, investors and creditors.

\subsection{The implementation of inflation accounting is to properly compensate the cost of production factors and maintain reproduction capacity}

For historical cost accounting, within foreseeable period, on accounting an enterprise will not recognize and reflect unrealized gains or losses of fixed assets because of price up and down, i.e. the enterprise will neither enjoy the benefits of price change nor suffer the losses of that. In the case of inflation, the income of traditional accounting is the real income of current period. But most of consumed assets among the matching cost were pre-purchased, which has been calculated on historical cost. In an inflation environment, with rising price, income and expenses lose the ratio based on the same price calculation, resulting in higher real income than the cost of inputs. Therefore, it inevitably results in inadequate cost compensation, threatens the scale of corporate reproduction, causes vicious circle, increases business risks, and is difficult to maintain simple reproduction.

\subsection{The implementation of inflation accounting is to correctly calculate corporate profit and loss}

If assets are calculated on historical cost, the costs in each period should be determined by the historical cost of consumed assets. In the case of inflation, the income that an enterprise gains is reflected by prevailing money purchase power, however, the matching costs and expenses mostly reflected previous money purchase power at low price. So the overestimation of gains and underestimation of cost must lead to inflated profits, and the profits derived from business can't accurately reflect current corporate performance. Therefore, the reflected business performance and corporate gain power are distorted. Under the inflation environment, the accounting information provided by traditional financial accounting statement is seriously false.

\subsection{The implementation of inflation accounting is to ensure the comparability of accounting information between enterprises}

The principle of comparability requires not only the accounting indicators approaches between enterprises be the same, i.e. comparable, but also those of the same enterprise be comparable in different accounting period. Because of inflation, the previous financial statements can be directly compared with current ones on values. But the statements users had better compare them on real volume, which often leads to conscious adjustment equivalent on price change level. Therefore, the accounting information provided by traditional historical cost accounting often does not meet the reality, whose relevance, comparability and adaptability are poor. In the case of high inflation rate, if we still base on the principle of historical cost and assumption of stable currency accounting and make accounting statements, but not correspondingly adjust and deal with it, the comparability of accounting information will not be that reliable.

\subsection{The implementation of inflation accounting is to improve corporate decision-making ability on investment}

False accounting information can cause corporate management level and investors make bad business decisions and investment decisions. Thus, it is difficult to make a correct assessment on business performance according to false accounting information. Even the bad decisions bring big mistakes to an enterprise, so it is hard to achieve the ultimate goal of the enterprise. When price rises, the non-discounted investment decision-making method is clearly no longer desirable. And the discount methods are more difficult due to the influence of inflation. Meanwhile, inflation easily leads to the rapid rise in capital flowing to the products or industries with faster price rise. If it is lack of necessary macro-control and restraint, it may result in unreasonable allocation of social resources and waste. Under the condition of inflation, traditional accounting model is has been difficult to accurately describe the real performance of the enterprise, therefore, it is imperative to seek measures to deal with inflation accounting and make accounting information accurately express business performance.

\subsection{The implementation of inflation accounting is to meet the international practice}

In order to weaken the impact of inflation to traditional accounting method, many countries adopt different 
inflation accounting treatment, and relevant international accounting organizations have also issued a number of provisions. As a member of WTO, China plays an increasingly important role in international trade, whose foreign accounting information attracts more attention from international community. So it is of practical significance to implement inflation accounting in China, which is the need for China to meet international practice and integrate with foreign accounting systems. We shall suggest establishing the inflation accounting model with Chinese characteristics and propose countermeasures to effectively eliminate the influence of inflation on accounting, through the comparison of inflation between China and other countries, analysis on the reasons of the differences, referring to international accepted inflation accounting model, and combining with China's national conditions.

\section{The mode selection of inflation accounting}

Current inflation accounting modes include: constant currency accounting, i.e. the traditional accounting by adjusting price level; current value accounting, i.e. current cost accounting; constant currency current value accounting, i.e. current cost accounting by adjusting price level. The above three modes are all general inflation accounting, with different characteristics and conditions of use.

\subsection{Constant currency accounting}

The so-called constant currency accounting is to translate each item of financial statement into constant price based on historical cost accounting, through setting a price index. The accounting information derived from constant currency accounting has comparability, which is easy to compare the financial situation and business performance in different periods. The information users are also able to learn about corporate real financial situation.

The main procedures of constant currency accounting are: (1) classify monetary items and non-monetary ones; (2) calculate profits and losses of purchasing power of monetary items; (3) adjust named currency amount of each non-monetary items in financial statement into stable currency value according to general price index; (4) restate financial statement according to the adjusted data.

The advantages of this accounting mode are: (1) the method is simple. The daily accounting is basically the same as the traditional accounting model, only adjusting the financial statement of traditional accounting mode through general price index; (2) Translate the historical currency representing the purchasing power in different periods into current currency, which strengthens the comparability of financial statements between different enterprises and different periods of the same enterprise; (3) The profit and loss of purchasing power of stated currency can reflect managerial ability to cope with inflation.

However, this accounting model also has its own shortcomings: (1) the useless of adjusted data decision is not strong. What general price index reflects is the price change of all products and services, but it is not necessarily the same with a specific price change relevant to certain enterprise. The data adjusted on general price level is neither real paid amount before, nor payable amount under current price level, which results in unmeaningful financial data; (2) compared to historical cost accounting model; statements need to be adjusted, leading to high cost. It is not that easy to understand the special meaning of adjusted data for statement users.

\subsection{Current value accounting}

The so-called current value accounting is based on current cost as measurement. This accounting model requires adjust book value of assets according to current cost, and then figure out the profits or losses of current assets which haven't been achieved due to the changes of current cost. Under this model, it is more close to the actual situation of corporate situation, avoiding some problems like inflated profits.

Current value accounting has the following main procedures: (1) Classify monetary items and non-monetary items, without adjustment on monetary items, but adjust non-monetary ones based on temporal current cost; (2) Figure out the held benefits of non-monetary items. The so-called held benefits refers to the difference between current cost and historical cost of non-monetary items, which derives from price rise, belongs to capital benefits, and can't be used for allocation. Only the difference between selling price and current cost, i.e. operating revenue is the real gains of enterprise for allocation; (3) Re-compilation of the existing cost-based financial statements.

The main advantages of this accounting model are: (1) The value of corporate assets is adjusted based on individual price level with price rise, therefore the valuation of assets is more realistic and at the same time strengthens the comparability of financial data; (2) The combination of calculated cost and income based on current cost can eliminate the phenomenon of inflated profits caused by current accounting model; (3) Distinguish corporate business profits from the profits and losses of held assets. Corporate profits and losses of 
held assets are aroused by market price change. And business profits are corporate business performance. To distinguish the above two can reflect not only the achievements that management authority manages assets, but also true business performance.

The main disadvantages of this accounting model are as follows. Firstly, the determination of replacement cost needs a lot of price information and complex calculations. When there is no market price, we can only estimate or calculate by price index with many subjective judgments. Secondly, poor comparability. The replacement costs in each period reflect the current value of assets in different periods, so they are hardly comparable. Thirdly, increase the difficulty of the audit. Moreover, general China's accounting personnel have low quality, so when determining replacement cost, in case of improper calculation, it will bring more serious unreal corporate costs. Fourthly, there is no consideration of changes of general price level. It doesn't calculate the profit and loss of purchasing power of monetary items, which causes consumed monetary currency not to be compensated. It doesn't meet the principle of capital preservation.

\subsection{Current value accounting of constant currency}

The so-called current value accounting of constant currency model refers to the combination of constant currency accounting and current value accounting. Under the constant currency accounting model, if we set a unified price change index and translate the amount of each item in the financial statement into constant price, we will neglect the influence of individual price change on corporate non-monetary assets, which results in big difference between the financial statement of constant currency and corporate real financial situation as well as business performance. Also current cost accounting model can't reflect the real purchasing power of constant monetary assets, so the losses brought to monetary assets due to price rise are covered. In this case, the constant current value accounting model comes into being.

In case of inflation, the selection of accounting model is often influenced by many factors. Firstly, we must consider the extent of price rise. For modest price rise, we usually use the constant currency accounting; for large price rise, we will adopt current value accounting; for serious price rise, like inflation, we often apply the current value accounting of constant currency. Secondly, we must consider the science and classification on making price index. The approaches and methods of China's price index making need to be further refined and improved to be with international standards, so that it can provide good basis for implementing inflation accounting. Thirdly, we must consider the selection cost of accounting models. The selection cost is different from model to model, which restrain our choice for proper accounting model, as current value accounting of constant currency has the highest cost. Fourthly, we must consider the impact of enterprise types and characteristics. Different types of enterprises have different assets structures, different business characteristics, and more different impacts suffering from inflation. Therefore, we should choose a different model of inflation accounting according to different characteristics of the enterprise, which will ensure the decision relevance of provided accounting information. Fifthly, we should consider the quality of accounting personnel. The implementation of inflation accounting has a high requirement on the quality of accounting personnel, so we need to select proper accounting model combining with the actual situation of accounting personnel.

\section{Accounting countermeasures to inflation}

Enterprises can take the following accounting countermeasures so as to eliminate the impact of inflation on accounting.

\subsection{Restate financial statement}

Restating financial statement means restating corporate financial statement according to purchasing power currency at the reporting date or current replacement cost, so as to correctly reflect the real value and business performance of corporate assets, liability and equity. Specifically, using the latest price index published by the government, we adjust and translate the assets, liability, income, expenses, and so on in the financial statement, so that they are restated according to current general purchasing power, which eliminate the impact of inflation. Secondly, we use current replacement cost as the basis of determination of assets valuation and profit and loss in order to detach from historical cost and value on current value rather than historical cost. It is the most radical approach to eliminate inflation, but with big difficulty and complicated process.

\subsection{Adjust assets book value on revaluation}

Periodic replacement of fixed assets valuation method means an enterprise revalue fixed assets with fixed period (quarter or year) on current full replacement value as the basis of adjusting book value and figure out depreciation, so as to reflect the current price of fixed assets, and make the depreciation consistent with the current cost. In the case of high inflation, common accounting methods value assets according to cost price and 
fixed depreciation rate. When current price is different from cost price, there will be distortion, i.e. serious underestimating fixed assets and net assets. For this case, we can use price index method, replacement cost method, current market price method, income approach and other methods to revalue fixed assets, guided by China's relevant assets valuation legislations and policies. It can eliminate the impact of inflation on accounting by adjusting assets value through revaluation.

\subsection{Encourage enterprises to use accelerated depreciation method}

Accelerated depreciation method means refers to more depreciation in the previous using period of fixed assets and later reducing of it. Enterprises' adopting accelerated depreciation method can not only shorten payback period, but also accelerate depreciation. It benefits more tax credit of previous depreciation cost, so as to comparatively increase corporate investment income and the product of deferred tax and investment income rate during the period. This method makes for the accelerated compensation of fixed assets cost during the using period, avoids possible risks, and enhances the development potential. However, the total depreciation of fixed assets is still historical cost, lower than replacement cost. The fixed assets on the balance sheet do not reflect its current value.

\subsection{Enhance inventory management and accounting}

In the case of inflation, one hand, an enterprise should fully consider the impact of price hikes on the stock. The use of LIFO, index adjustment method or the monthly final purchase price as cost in order for re-valuation and consumption accounting on inventory can minimize the loss of stock. On the other hand, an enterprise needs to consider the demand decrease on enterprise products due to national deflation policies, social investment, consumption, exports and other aspects. Therefore, an enterprise should balance advantages and disadvantages according to its own conditions, and reserve an appropriate amount of inventory. In addition, the enterprise needs to enter into long-term purchase contracts with customers to reduce the losses caused by price rise.

\subsection{Fully consider the inflation risks in long-term investment decisions}

In the case of high inflation, the investment decision of non-discount is not desirable due to ignoring the time value of money, such as accounting rate of return, payback period and so on. In long-term investment decision, the investment decision of discount should be adopted, but in the determination of discount rate, we should not only consider interest rate or yield rate, but also consider the inflation risks. Therefore, in exterminating discount rate, we should take the sum of interest rate and inflation rate as discount rate, in order to make scientific and long-term investment decision.

\subsection{Allow enterprises to extract the reserve of price change}

In the case of high inflation, as price increases, the compensation value based on historical cost is not enough to compensate the raw materials during production process, plant, equipment and other production factors. Furthermore, the longer of the interval period between assets purchase and consumption, the bigger of the difference between current cost and historical cost. Therefore, it is necessary to extract reserve of price change based on current price, for some raw materials and equipment with heavy price fluctuation. Only in this way, can we balance assets consumption and compensation, ensure enterprise reproduction capacity, preserve capital, and guarantee the rights of investors and creditors.

\section{References}

Gu Jijian. (2008). On inflation and its impact on investment. SAR Economy. 2008, (1).

Hao Zhenping. (2004). International Accounting. Lixin Accounting Press.

Hao Xiangrong. (2003). The applying situation and prospects of fair value measurement attributes. Accounting Monthly. 2003, 16.

Li Zhenggang. (2008). On inflation accounting. China's township enterprises accounting. 2008, (2).

Zhou Xiaosu. (2001). On Accounting Models in China. Finance Northeastern University Press. 